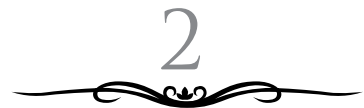

\title{
PEMETAAN KEBUTUHAN SDM BERDASARKAN ANALISIS BEBAN KERJA (ABK) DAN MUTU LAYANANPERPUSTAKAAN DI PUSAT PERPUSTAKAAN UIN MAULANA MALIK IBRAHIM MALANG
}

\author{
Mufid dan Wahyuningtyas \\ UIN Malang, Jawa Timur, Indonesia \\ mufid@uin-malang.ac.id
}

\begin{abstract}
The focus of this research is the development of human resources in the Library of Maulana Malik Ibrahim State Islamic University of Malang. This study aims to examine the human resource needs in the library based on the workload of library services. Workload analysis and the service quality are used as the research methods. The Workload Analysis is measured using performance indicators in five areas / coordinators in the organizational structure of the library and the service quality use five indicators / dimensions of sevice quality that have been developed from SERVQUAL. The finding suggests that there is a gap between the human resource needs with the workload and the service quality. Based on the result, the analysis can be used as a guideline in satisfying the human resource needs in the Library of Maulana Malik Ibrahim State Islamic University of Malang.
\end{abstract}

Keywords: Workload Analysis, Services Quality Analysis, Human Resource Development, Human Resource Needs 


\begin{abstract}
Abstrak
Fokus dalam penelitian ini adalah pengembangan sumber daya manusia (SDM) PusatPerpustakaan UIN Maulana Malik Ibrahim Malang. Tujuan penelitian ini adalah untuk mengetahui kebutuhan SDM Pusat Perpustakaan UIN Maulana Malik Ibrahim Malang sesuai dengan beban kerja layanan perpustakaan yang disediakan.Metode yang digunakan adalah Analisis Beban kerja $(\mathrm{ABK})$ dan mutu layanan. ABK diukur dengan menggunakan indikator kinerja pada lima bidang/koordinator layanan yang sesuai dalam struktur organisasi perpustakaan. Sedangkan mutu layanan menggunakan indikator lima aspek/ dimensi mutu layanan yang dikembangkan dari model Servqual. Temuan dalam penelitian ini adalah terdapat gap/kesenjangan antara kebutuhan SDM dengan beban kerja dan mutu layanan. Rekomendasi dalam penelitian ini adalah hasil kedua analisis tersebut dapat dijadikan pedoman pengembangan SDM dalam memetakan kebutuhan SDM Pusat Perpustakaan UIN Maulana Malik Ibrahim yang ideal.
\end{abstract}

Kata kunci: Analisis Beban Kerja, Analisis Mutu Layanan, SDM Perpustakaan

\title{
A. Pendahuluan
}

Perpustakaan perguruan tinggi merupakan bagian integral dari kegiatan pendidikan, penelitian dan pengabdian kepada masyarakat dan berfungsi sebagai pusat sumber belajar untuk mendukung tercapainya tujuan pendidikan. ${ }^{1}$ Fungsi dan tujuan tersebut dapat tercapai secara optimal jika manajemen layanan dijalankan dengan profesional.

Peran SDM menjadi sangat penting dalam mengoptimalisasi fungsi perpustakaan perguruan tinggi secara bermutu dan profesional. Perpustakaan dituntut memiliki SDM yang memadai baik secara kualitas maupun kuantitas. Oleh karena

${ }^{1}$ Kementerian Sekretaris Negara RI, "Peraturan Pemerintah Republik Indonesia Nomor 24 Tahun 2014 Tentang Pelaksanaan Undang-Undang Nomor 43 Tahun 2007 Tentang Perpustakaan" (Jakarta, 2014), hlm. 3. 
itu, untuk menuju perpustakaan berkualitas bertaraf nasional dan internasional, Pusat Perpustakaan UIN Maulana Malik Ibrahim Malang perlu dikelola oleh SDM secara professional dalam menjalankan tugas dan fungsinya dengan

Arah pengembangan SDM Pusat Perpustakaan sejalan dengan amanah Sembilan Program Garis Besar Haluan Universitas (GBHU) UIN Maulana Malik Ibrahim Malang sebagai landasan untuk mencapai tahapan regional recognition and reputation ${ }^{2}$. Pengembangan SDM perpustakaan menjadi sangat penting sebagai titik awal untuk melakukan pengembangan internasionalisasi perpustakaan menuju library for world class University.

Bermula dari keikutsertaan Pusat Perpustakaan UIN Maulana Malik Ibrahim Malang dalam sertifikasi ISO 9001:2000 dan 9001:2008 3 adalah sebagai upaya untuk meningkatkan pelayanan perpustakaan yang bermutu. Namun pada implementasinya, besarnya kontribusi mutu layanan Pusat Perpustakaan terhadap kepuasan hanya sebesar 64.9\%. Rendahnya mutu layanan karena kompetensi SDM perpustakaan yang kurang memadai ${ }^{4}$. Kompetensi SDM yang ada saat ini kurang mampu menjawab kebutuhan informasi pemustaka sehingga pelayanan yang diberikan kurang mampu memenuhi harapan pemustaka.

Di samping persoalan kompetensi SDM, rendahnya mutu layanan juga dipengaruhi oleh beban kerja organisasi yang berlebihan $^{5}$. Berdasarkan hasil penelitian, beban kerja organisasi

${ }^{2}$ UIN Malang, Rencana Strategis UIN Malang 2005-2030 (Malang: UIN Malang, 2005).

${ }^{3}$ UIN Malang, Implementasi Sistem Manajemen Mutu ISO 9001:2000 Di Universitas Islam Negeri (UIN) Malang (Malang: UIN Malang, 2008).

${ }^{4}$ Mufid, "Pengaruh Mutu Layanan Terhadap Kepuasan Pemustaka: Studi Kasus Di Perpustakaan Pusat UIN Maulana Malik Ibrahim Malang Kutipan Saya” (Universitas Indonesia, 2011), 83. http://repository.uin-malang. ac.id/693/.

${ }^{5}$ W Hariyono, D Suryani, and Y Wulandari, "Hubungan Antara Beban Kerja, Stres Kerja Dan Tingkat Konflik Dengan Kelelahan Kerja Perawat Di Rumah Sakit Islam Yogyakarta Pdhi Kota Yogyakarta," Kesmas 3, no. 3 (1978), 
yang berlebihan tidak sesuai dengan SDM yang ada akan mempengaruhi tingkat stress ${ }^{67}$ sehingga memungkinkan kinerja SDM menurun. Hal ini sesuai dengan teori manajemen bahwa Sumberdaya Manusia (SDM) menjadi penentu utama keberhasilan dalam menjalankan organisasi.

Berdasarkan uraian di atas, Pusat Perpustakaan perlu melakukan kajian pengembangan SDM dengan berpedoman pada standar perpustakaan perguruan tinggi sehingga dapat diketahui kondisi SDM sekarang dan kebutuhan SDM di masa datang. Dengan harapan, melalui kajian yang mendalam, SDM Pusat Perpustakaan dalam lima tahun kedepan dapat memenuhi kriteria SDM perpustakaan perguruan tinggi bertaraf internasional.

Dalam penelitian ini bertujuan untuk mengetahui kebutuhan SDM Pusat Perpustakaan UIN Maulana Malik Ibrahim Malang dalam memenuhi kebutuhan standar Library for World Class University yang mencakup:

1. Mengetahui kondisi jumlah dan kompetensi SDM yang dimilikiPusat Perpustakaan UIN Maulana Malik Ibrahim Malang;

2. Mengetahui jumlah tenaga fungsional pustakawan dan non pustakawan yang dibutuhkan Pusat Perpustakaan UIN Maulana Malik Ibrahim Malang dalam waktu 5 (lima) tahun ke depan;

3. Menentukan kompetensi SDMyang dibutuhkan oleh Pusat Perpustakaan UIN Maulana Malik Ibrahim Malang;

4. Melakukan pemetaan SDM di Pusat Perpustakaan UIN

hlm. 196.

6 Zurni Zahara Samosir and Iin Syahfitri, "Faktor Penyebab Stres Kerja Pustakawan Pada Perpustakaan Universitas Sumatera Utara," Pustaha 4, no. 2 (2008): 68, http://ced.petra.ac.id/index.php/pus/article/ download/17236/17191.

${ }^{7}$ W Hariyono, D Suryani, and Y Wulandari, "Hubungan Antara Beban Kerja, Stres Kerja Dan Tingkat Konflik Dengan Kelelahan Kerja Perawat Di Rumah Sakit Islam Yogyakarta PDHI Kota Yogyakarta," Kesmas 3, no. 3 (2009): hlm. 169, http://jogjapress.com/index.php/KesMas/article/view/546. 
Maulana Malik Ibrahim Malang.

\section{B. Pembahasan}

\section{Konsep Pengembangan Sumberdaya Manusia}

Werner dan Desimone ${ }^{8}$ mendefinisikan pengembangan sumber daya manusia (human resources development) sebagai serangkaian aktivitas yang sistematis dan terencana yang dirancang oleh organisasi untuk memberikan kesempatan kepada anggotanya untuk mempelajari keahlian yang diperlukan dalam memenuhi persyaratan kerja saat ini dan yang akan datang.

Perpustakaan sebagai organisasi penyedia jasa informasi tentu saja memiliki karakteristik yang unik dan khas jika dibandingkan dengan organisasi lainnya, termasuk dalam hal SDM. Penambahan jumlah SDM perpustakaan (kuantitas) harus memperhatikan kompetensi yang dibutuhkan (kualitas) oleh perpustakaan. Standar kompetensi SDM Perpustakaan/ pustakawan menurut SLA ${ }^{9}$ meliputi kompetensi profesional dan kompetensi personal.

Kompetensi profesional berkaitan dengan pengetahuan pustakawan tentang sumberdaya informasi, akses, teknologi dan manajemen informasi, serta kemampuan pustakawan untuk menggunakan pengetahuan sebagai dasar memberikan pelayanan informasi yang bermutu. Empat kompetensi utama pada kompetensi profesional, yaitu: mengelola organisasi informasi, mengelola sumberdaya informasi, mengelola layanan informasi, dan menerapkan teknologi informasi.

Sedangkan kompetensi personal merupaka kompetensi yang berkaitan dengan sikap, ketrampilan dan nilai yang

${ }^{8}$ Jon M Werner and Randy L DeSimone, Human Resource Development (South-Western Cengage Learning, 2011), hlm. 4.

9 The Special Libraries Association, "Competencies for Information Professionals of the 21st Century," The Special Libraries Association, 2003, http://sla.org/wp-content/uploads/2013/01/0\{_\}LRNCompetencies2003\{_\} revised.pdf. 
memungkinkan pustakawan untuk bekerja secara efektif dan berkontribusi secara positif pada organisasi, pemustaka dan profesinya.

\section{Konsep Analisis Beban Kerja}

Analisis beban kerja adalah suatu teknik manajemen yang dilakukan secara sistematis untuk memperoleh informasi mengenai tingkat efektivitas dan efisiensi kerja organisasi berdasarkan volume kerja ${ }^{10}$.

Dalam kontek organisasi perpustakaan, analisis beban kerja dilaksanakan untuk menciptakan efektivitas dan efisiensi serta profesionalitas SDM perpustakaan yang memadai serta mampu melaksanakan tugas-tugas layanan perpustakaan secara profesional.

Selain itu, Analisis Beban Kerja dilaksanakan untuk menghasilkan suatu tolok ukur bagi SDM perpustakaan dalam melaksanakan tugasnya, yaitu berupa norma waktu penyelesaian kerja, tingkat efisiensi kerja, standar beban dan prestasi kerja, penyusunan formasi pegawai, penyempurnaan sistem prosedur kerja dan manajemen lainnya.

\section{Konsep Mutu Layanan Perpustakaan}

Mutu layanan adalah "as perceived by consumers, stems from a comparison of what they feel service firms should offers with their perceptions of the performance of firms providing the services" ${ }^{11}$. Jadi mutu layanan itu merupakan perbedaan antara harapan dan persepsi pengguna berkenaan dengan layanan yang diberikan oleh layanan perusahaan. Dalam konteks ini, peneliti mendefinisikan mutu layanan perpustakaan adalah keunggulan

10 Kementerian Agama RI, Keputusan Menteri Agama Republik Indonesia Nomor 164 Tahun 2010 Pedoman Pelaksanaan Analisis Beban Kerja (Workload Analysis) Di Lingkungan Kementerian Agama (Jakarta: Kementerian Agama RI, 2010).

${ }^{11}$ A Parasuraman, Valarie A Zeithaml, and Leonard L Berry, "Servqual: Multiple Item Scale for Measuring Consumer Perseption of Service Quality," Journal of Retailing 64, no. 1 (1988), hlm. 16. 
seluruh layanan perpustakaan yang memberikan kepuasan terhadap harapan semua pemustaka di lingkungan UIN Maulana Malik Ibrahim Malang.

Untuk analisis mutu layanan menggunakan lima aspek model SERQUAL yaitu:Berwujud (tangibles); penampilan fasilitas fisik, staf, sarana dan alat komunikasi;Reliabilitas (reliability); kemampuan menjalankan layanan yang diterapkan dengan handal dan akurat; Daya tanggap (responsiveness); kesediaan membantu pengguna dan memberikan layanan tepat waktu;Jaminan (assurance); petugas memiliki pengetahuan, kesopanan dan memiliki kemampuan untuk memberikan kepercayaan dan rasa percaya diri; dan, Empati (empathy); kepedulian, perhatian terhadap kebutuhan pengguna ${ }^{12}$.

\section{Hubungan Mutu Layanan Terhadap Kepuasan Pemustaka}

Mutu layanan perpustakaan memiliki hubungan yang sangat erat dengan kepuasan pemustaka ${ }^{13}$. Tingkat mutu layanan perpustakaan memberikan dampak pada kepuasan pemustaka. Semakin bermutu layanan perpustakaan maka semakin meningkat kepuasan pemustaka.

Dari limaaspek mutu layanan perpustakaan, aspek empati dan reliabilitas / kehandalan staf perpustakaan memiliki pengaruh paling kuat dalam meningkatkan kepuasan pemustaka ${ }^{14}$. Perhatian staf ini dapat berupa bantuan penggunaan katalog, penelusuran informasi buku di rak, memberikan rujukan dan lain-lain. Kemudian kehandalan staf meliputi sikap yang sopan terhadap pemustaka, mampu memberikan jawaban dan solusi secara tepat atas kesulitan yang dihadapi pemustaka.

\section{${ }^{12}$ Ibid. : 23}

${ }^{13}$ G S Sureshchandar, C Rajendran, and R N Anantharaman, "The Relationship between Service Quality and Customer Satisfaction - AfactorSpecific Approach," Journal of Service Marketing 16, no. 4 (2002), hlm. 372.

${ }^{14}$ Muhammad Usman Awan, S Azam, and Muhammad Asif, "Library Service Quality Assessment," Journal of Quality and Technology Management 4, no. 1 (2008),hlm. 60. 


\section{Hubungan Antara Beban Kerja dan Mutu Layanan Perpustakaan terhadap Kinerja SDM Perpustakaan}

Berdasarkan hasil penelitian yang diuraikan pada bab pendahuluan, beban kerja dan mutu layanan sangat erat kaitannya dengan kinerja SDM perpustakaan. Beban kerja yang berlebihan, tidak sesuai dengan jumlah SDM perpustakaan akan membuat pegawai cepat stres dan akan menjadi pemicu turunnya kinerja pegawai. Sementara tingkat mutu layanan akan mempengaruhi tingkat kepuasan pemustaka. Mutu layanan yang rendah akan memicu kepuasan pemustaka yang rendah.

Oleh karena itu dalam pengembangan SDM perpustakaan perlu melakukan pemetaan terlebih dahulu mengenai beban kerja yang diemban oleh perpustakaan dan kompetensi pegawai yang dibutuhkan. Kompetensi pegawai ini merupakan penentu utama dalam menjalankan perpustakaan secara ideal dan profesional.

\section{Metode Penelitian}

Metode penelitian pengembangan SDM perpustakaan menggunakan dua pendekatan yaitu analisis beban kerja tugastugasyang dijalankan di setiap Koordinator Layanan dalam struktur organisasi perpustakaan.ABK bertujuan untuk mengetahui beban kerja masing-masing Koordinator Layanan dan jumlah pegawai yang dibutuhkan.Kebutuhanpegawai disesuaikan dengan tingkat kebutuhan pekerjaan yang diemban oleh setiap koordinator. Tugas pada setiap Koordinator Layanan mulai dari tugas layanan yang bersifat administrasi, teknis dan yang membutuhkan skill dan pengetahuan.

Instrument ABK yang diukur adalah indikator beban kerja pada Bidang Administrasi dan Keuangan, Bidang Pengembangan Koleksi, Bidang Layanan Teknis/ Pengolahan, Bidang Layanan Pemustaka dan Bidang Pengembangan Teknologi Informasi berdasarkan Job Description dan Standard Operational Procedure (SOP). Kemudian untuk menentukan indikator kompetensi pustakawan yang dibutuhkan berdasarkan indikator kinerja 
yang dijelaskan dalam Permenpan-RB No 9 Tahun 2014 ${ }^{15}$. Untuk beban kerja Kepala dan Sekretaris dalam struktur organisasi Pusat Perpustakaan tidak diuraikan karena sudah jelas kebutuhannya, sehingga jumlah kebutuhan keseluruhan hasil $A B K$ adalah jumlah kebutuhan SDM seluruh koordinator dan bagian administrasi dan keuangan.

Disamping $\mathrm{ABK}$, pendekatan lain yang digunakan untuk mengetahui kebutuhan SDM adalah analisis mutu layanan dengan menggunakan limaaspek model SERQUALyang meliputi lima dimensi mutu yaitu tangible, responsiveness, assurance, empathy, dan reliability. Analisis mutu layanan bertujuan untuk memahami seberapa besar mutu layanan yang tersedia mampu memenuhi harapan pengguna yang bermuara pada kepuasan.Dengan memahami tingkat mutu layanan, maka dapat diketahui kebutuhan dan harapan pengguna yang mana yang perlu ditingkatkan sehingga dapat membantu dalam pemetaan kebutuhan SDM perpustakaan.Hasil pengukuran mutu ini dapat diketahui tingkat mutu perpustakaan dan dapat menjadi masukan yang sangat berharga bagi pengembangan SDM perpustakaan, termasuk SDM perpustakaan yang ideal.

Populasi penelitian untuk kegiatan ABK adalah seluruh pegawai Pusat Perpustakaan UIN Maulana Malik Ibrahim Malang yaitu sebanyak 22 orang.Keseluruhan pegawai dijadikan sampel penelitian.Sedangkan untuk analisis mutu layanan perpustakaan adalah seluruh mahasiswa UIN Maulana Malik Ibrahim Malang yang terdaftar sebagai anggota perpustakaan.Sedangkan sampelnya adalah wakil dari populasi.

Sampel pada kegiatan analisis mutu layanan menggunakan teknik Simple Random Sampling untuk anggota populasi dengan memberi angket kuesioner langsung mahasiswa yang sedang memanfaatkan layanan Pusat Perpustakaan UIN Maulana Malik

15 Kemenpan-RB RI, Peraturan Menteri Pendayagunaan Aparatur Negara Nomor Dan Reformasi Birokrasi Republik Indonesia Nomor 9 Tahun 2014 Tentang Jabatan Fungsional Pustakawan Dan Angka Kreditnya (Indonesia, 2014)., hlm. 11. 
Ibrahim Malang pada saat penelitian ini dilakukan. Sampel yang digunakan dalam penelitian ini sejumlah 200 pemustaka.

Teknik pengumpulan data dilakukan dengan dua tahapan:

a. Tahap Analisis Beban Kerja (ABK), meliputi:

1) Memahami organisasi seperti visi, misi, struktur organisasi, mekanisme kerja, volume kegiatan, proses bisnis dari Pusat Perpustakaan UIN Maulana Malik Ibrahim Malang.

2) Melakukan sosialisasi kepada seluruh pegawai tentang cara pengisian formulir $\mathrm{ABK}$

3) Pengisian formulir oleh masing-masing bidang layanan;

4) Melakukan analisis dan validasi data dan informasi yang diperoleh;

5) Melakukan wawancara dengan beberapa koordinator bidang layanan;

6) Membuat laporan hasil kajian.

b. Tahap mengukur mutu layanan dilakukan dengan cara menyebarkan kuesioner kepada sampel penelitian untuk mendapatkan data primer dan penelusuran dokumentasi untuk mendapatkan data sekunder. Kuesioner berisi pernyataan-pernyataan berdasarkan pengukuran skala likert. Untuk kuesioner mutu layanan memiliki lima alternatif jawaban dan bobot nilai yaitu sangat puas = 5 , puas $=4$, cukup puas $=3$, kurang puas $=2$, tidak puas $=1$.

c. Studi kepustakaan, dilakukan dengan cara membaca dan mengutip langsung dan tidak langsung dari literatur yang berkaitan dengan variabel penelitian.

Dalam kegiatan ABK, setelah analisis beban kerja dalam kurun 1 tahun pada tiap-tiap koordinator layanan selesai, maka jumlah beban kerja tersebut dilakukan analisis penghitungan kebutuhan pegawai perpustakaan dengan menggunakan rumus yang berdasarkan pada Peraturan Perpustakaan Nasional RI, yaitu: 


\begin{tabular}{|ll|}
\hline $\mathrm{JF}=$ & $\mathrm{W} / \mathrm{JKE}$ Orang \\
$\mathrm{W}=$ & Jumlah waktu yang diperlukan untuk \\
& menyelesaikan tugas \\
$\mathrm{JKE}=$ & Jam kerja efektif setiap orang
\end{tabular}

Sementara untuk analisis mutu layanan, data yang terkumpul diolah dengan menggunakan bantuan Microsoft excel untuk mendeskripsikan lima variabel mutu layanan tersebut.

\section{Deskripsi Analisis Beban Kerja dan SDM yang Dibutuhkan}

Berdasarkan hasil analisis beban kerja pada lima bidang/ koordinator layanan Pusat UIN Maulana Malik Ibrahim Malang, maka dapat diketahui besarnya beban kerja keseluruhan tugas pelayanan dan SDM yang dibutuhkan di Pusat Perpustakaan UIN Maulana Malik Ibrahim Malang. Beban kerja keseluruhan [unit] dan SDM yang dibutuhkan di Pusat Perpustakaan ditunjukkan pada Tabel 1 .

Tabel. 1

Hasil Analisis Beban Kerja Keseluruhan Koordinator dan SDM yang dibutuhkan di Pusat Perpustakaan UIN Maulana Malik Ibrahim Malang

\begin{tabular}{cccccc}
\hline NO & TUGAS LAYANAN & OUTPUT & $\begin{array}{c}\text { JUMLAH } \\
\text { NORMA } \\
\text { WAKTU }\end{array}$ & $\begin{array}{c}\text { JUMLAH } \\
\text { SDM }\end{array}$ \\
\hline 1 & $\begin{array}{c}\text { Bidang Administrasi } \\
\text { dan Keuangan }\end{array}$ & 16,638 & 104,120 & $3 \%$ & 1 \\
\hline 2 & $\begin{array}{c}\text { Koordinator } \\
\text { Pengembangan } \\
\text { Koleksi }\end{array}$ & 46,504 & 276,320 & $8 \%$ & 4 \\
\hline 3 & $\begin{array}{c}\text { Koordinator } \\
\text { Pengolahan Koleksi }\end{array}$ & 178,613 & $1,544,380$ & $45 \%$ & 21 \\
\hline 4 & $\begin{array}{c}\text { Koordinator } \\
\text { Pelayanan Pemustaka }\end{array}$ & $1,444,867$ & $1,447,590$ & $42 \%$ & 19 \\
\hline 5 & $\begin{array}{c}\text { Koordinator } \\
\text { Pengembangan TI }\end{array}$ & 10,653 & 81,900 & $2 \%$ & 1 \\
\hline & $\begin{array}{c}\text { JUMLAH BEBAN } \\
\text { KERJA UNIT }\end{array}$ & $1,697,275$ & $3,454,310$ & $100 \%$ & 46 \\
\hline
\end{tabular}


Dari Tabel di atas menunjukkan bahwa kebutuhan kebutuhan SDM Pusat Perpustakaan UIN Maulana Malik Ibrahim Malang sejumlah 46 orangyaitu bidang administrasi dan Keuangan 1 (satu) orang, Koordinator PengembanganKoleksi 4 (empat) orang, Koordinator Pengolahan Koleksi 21 (dupuluh satu)orang, Koordinator Layanan 19 (Sembilan belas) orang, dan Koordinator Pengembangan TI 1 (satu) orang.

Beban kerja dan SDM yang dibutuhkan perpustakaan yang paling besar adalah bidang pengolahan koleksi [45\%], kemudian diikuti oleh bidang pelayanan pemustaka [42\%], bidang pengembangan koleksi[8\%], bidang administrasi dan keuangan[3\%], dan yang paling sedikit beban kerjanya adalah bidang pengembangan teknologi informasi [2\%]. Untuk lebih jelasnya persentase beban kerja ditunjukkan pada Grafik 1.

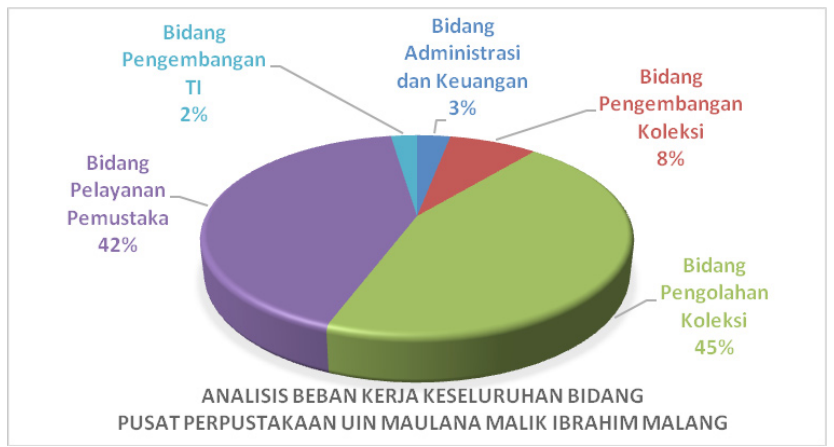

Grafik 1. Persentase Beban Kerja Koordinator di Pusat Perpustakaan UIN Maulana Malik Ibrahim Malang

a. Tenaga Fungsional Pustakawan dan Non Pustakawan yang Dibutuhkan Pusat Perpustakaan UIN Maulana Malik Ibrahim Malang Dalam Waktu 5 (Lima) Tahun Ke Depan

Selanjutnya, dari jumlah keseluruhan kebutuhanSDM perpustakaan tersebut kemudian dipetakan ke dalam tingkat pekerjaannya untuk mengetahui kualifikasi pendidikan yang dibutuhkan. Hasil pemetaan kebutuhan berdasarkan kualifikasi pendidikan ditunjukkan pada Tabel 2. 
Tabel 2. Kebutuhan SDM Berdasarkan Kualifikasi Pendidikan

\begin{tabular}{cccc}
\hline $\begin{array}{c}\text { Kualifikasi Pendidikan Yang } \\
\text { Dibutuhkan }\end{array}$ & Menit & Jam & Kebutuhan SDM \\
\hline S1 Ilmu Perpustakaan & 816,050 & 13,601 & 11 \\
\hline S1 non Ilmu Perpustakaan & 94,520 & 1,575 & 1 \\
\hline D3 Perpustakaan & $1,931,500$ & 32,192 & 26 \\
\hline SMA & 530,340 & 8,839 & 7 \\
\hline S1 TI & 81,900 & 1,365 & 1 \\
\hline Total & $3,454,310$ & 57,572 & 46 \\
\hline
\end{tabular}

Tabel di atas, menunjukkan bahwa kebutuhan SDM untuk penyelenggaraan layanan Pusat Perpustakaan berdasarkan kualifikasi pendidikan untuk S1 Ilmu perpustakaan 11 (sebelas) orang, S1 Non Ilmu Perpustakaan 1 (tiga) orang, , S1 TI 1 (satu) orang, D3 Perpustakaan 26 (duapuluh enam) orang, dan tingkat SMA 7 (tujuh) orang.

Kemudian untuk mengetahui sebaran atau formasi kualifikasi pendidikan di setiap koordinator layanan ditunjukkan pada Tabel 3.

Tabel 3. Formasi Kebutuhan Pegawai Berdasarkan Kualifikasi Pendidikan

\begin{tabular}{lccccccc}
\hline No & $\begin{array}{c}\text { Kualifikasi } \\
\text { Pendidikan } \\
\text { Yang } \\
\text { Dibutuhkan }\end{array}$ & $\begin{array}{c}\text { Adm } \\
\text { Keu }\end{array}$ & $\begin{array}{c}\text { Pengem- } \\
\text { bangan } \\
\text { Koleksi }\end{array}$ & $\begin{array}{c}\text { Pengo- } \\
\text { lahan } \\
\text { Koleksi }\end{array}$ & $\begin{array}{c}\text { Layanan } \\
\text { Pemus- } \\
\text { taka }\end{array}$ & $\begin{array}{c}\text { Peng. } \\
\text { TI }\end{array}$ & Jumlah \\
\hline 1 & $\begin{array}{c}\text { S1 Ilmu } \\
\text { Perpustakaan }\end{array}$ & 0 & 1 & 9 & 1 & 0 & 11 \\
\hline & $\begin{array}{c}\text { S1 non Ilmu } \\
\text { Perpustakaan }\end{array}$ & 1 & 0 & 0 & 0 & 0 & 1 \\
3 & S1 TI & 0 & 0 & 0 & 0 & 1 & 1 \\
4 & $\begin{array}{c}\text { D3 } \\
\text { Perpustakaan }\end{array}$ & 0 & 3 & 12 & 11 & 0 & 26 \\
5 & SMA & 0 & 0 & & 7 & 0 & 7 \\
\hline & Jumlah Total & 1 & 4 & 21 & 19 & 1 & 46 \\
\hline
\end{tabular}

Hasil ABK di atas, menunjukkan kebutuhan tenaga perpustakaan pada seluruh koordinator layanan adalah 46 orang 
(belum termasuk unsur kepala, dan sekretaris), sementara jumlah SDM perpustakaan saat ini adalah26 orang (termasuk, kepala dan sekretaris).

b. Deskripsi Mutu Layanan Perpustakaan

Selain melakukan pemetaan kebutuhan SDM berdasarkan beban kerja unit, juga melakukan survei mutu layanan perpustakaan tentang tingkat kepuasan pemustaka terhadap layanan perpustakaan. Hasil survei ini dapat dijadikan sebagai indikator untuk mengetahui kompetensi pegawai dalam melaksanakan tugas-tugas layanan perpustakaan. Hasil survey ditunjukkan pada Tabel 4.

Tabel 4. Persentase Jawaban Responden tentang Tingkat Kepuasan

Pemustaka Pusat perpustakaan UIN Maulana Malik Ibrahim Malang Tahun 2015

\begin{tabular}{lcccccc}
\hline Dimensi & $\begin{array}{c}\text { Tidak } \\
\text { Puas }\end{array}$ & $\begin{array}{c}\text { Kurang } \\
\text { Puas }\end{array}$ & $\begin{array}{c}\text { Cukup } \\
\text { Puas }\end{array}$ & Puas & $\begin{array}{c}\text { Sangat } \\
\text { Puas }\end{array}$ & (\%) \\
\hline Reliability & $1 \%$ & $8 \%$ & $28 \%$ & $42 \%$ & $21 \%$ & $100 \%$ \\
Responsiveness & $1 \%$ & $5 \%$ & $28 \%$ & $45 \%$ & $21 \%$ & $100 \%$ \\
Assurance & $2 \%$ & $12 \%$ & $30 \%$ & $37 \%$ & $19 \%$ & $100 \%$ \\
Empathy & $3 \%$ & $16 \%$ & $39 \%$ & $30 \%$ & $12 \%$ & $100 \%$ \\
Tangible & $4 \%$ & $16 \%$ & $28 \%$ & $32 \%$ & $21 \%$ & $100 \%$ \\
\hline
\end{tabular}

Dari Tabel di atas, menggambarkan bahwa mutu layanan perpustakan pada lima aspek yaitu reliability (kehandalan), responsiveness (daya tanggap), assurance (jaminan), empathy (empati), dan tangible (berwujud), semuanya masih terdapat pelayanan tidak memuaskan. Sejumlah $16 \%$ jawaban responden memberikan persepsi bahwa pelayanan perpustakaan kurang memuaskan padaaspekempatistafterhadap pemustakadanfasilitas yang tersedia juga mendapat sorotan kurang memuaskan sebesar $16 \%$. Lalu jawaban responden pada aspekResponsivenesssebesar $45 \%$ memberikan rasa puas, dan $21 \%$ memuaskan.

Hasil survey ini secara umum menggambarkan bahwa pelayanan perpustakaan pada Pusat perpustakaan UIN Maulana Malik Ibrahim Malang masih terdapat pelayanan yang tidak 
memuaskan, walaupun persentasenya kecil. Seharusnya, pelayanan perpustakaan paling tidak akan memberikan pada tingkat kepuasan "cukup puas” bagipemustaka.

Dalam persepsi pemustaka, kinerja staf perpustakaan pada lima aspek tersebut masih dianggap oleh sebagian kecil pemustaka tidak memuaskan dalam memberikan pelayanan. Kinerja yang tidak memuaskan ini, dapat disebabkan oleh minimnya jumlah staf, dan kualifikasi pendidikan staf yang sebagian besar tidak sesuai dengan kebutuhan perpustakaan perguruan tinggi. Kurangnya pemahaman terhadap tugas-tugas librarianship juga sebagai pemicu ketidak puasan pemustaka

Atas dasaritu maka perlu ada upaya program pengembangan SDM berkelanjutan baik secara kuantitas maupun kualitasnya dalam rangka untuk meningkatkan pelayanan perpustakaan kearah yang lebih baik lagi. Secara kuantitas, pengembangan dilakukan dengan cara perekrutan SDM yang memiliki kualifikasi pendidikan perpustakaan. Dan secara kualitas, peningkatan SDM dapat dilakukan dengan membuat program-progam yang berkaitan dengan continuing professional development, antara lain menyelenggarakan seminar, webinar, pelatihan-pelatihan yang berkaitan dengan pelayanan prima, dan lain-lain.

c. Pemetaan Kebutuhan SDM Berdasarkan Analisis Beban Kerja (ABK) dan Mutu Layanan Perpustakaan

Hasil ABK dan survey mutu layanan di atas, dapat digunakan untuk melakukan pemetaan kebutuhan SDM perpustakaan. Pemetaan ini sebagai salah satu upaya untuk perencanaan pengembangan SDM perpustakaan kearah ideal. Hasil pemetaan ditunjukkan pada Tabel 5.

Tabel 5. Pemetaan Kebutuhan SDM Berdasarkan Analisis Beban Kerja

Pegawai Pusat Perpustakaan UIN Maulana Malik Ibrahim Malang

\begin{tabular}{lccccc}
\hline No & $\begin{array}{c}\text { Kualifikasi } \\
\text { Pendidikan } \\
\text { (minimal) }\end{array}$ & $\begin{array}{c}\text { Jumlah } \\
\text { tenaga } \\
\text { Ideal }\end{array}$ & $\begin{array}{c}\text { Jumlah } \\
\text { tenaga yang } \\
\text { tersedia }\end{array}$ & $\begin{array}{c}\text { Jumlah } \\
\text { Tenaga yang } \\
\text { dibutuhkan } \\
(\mathrm{c}-\mathrm{d})\end{array}$ & $\begin{array}{c}\text { Jumlah } \\
\text { tenaga yang } \\
\text { berlebih } \\
(\mathrm{d}-\mathrm{c})\end{array}$ \\
\hline$a$ & $b$ & $c$ & $d$ & $e$ & $f$
\end{tabular}




\begin{tabular}{llllll}
1 & S2 Ilmu & 2 & 0 & 0 \\
2 & $\begin{array}{l}\text { Perpustakaan } \\
\text { S1Ilmu } \\
\text { Perpustakaan }\end{array}$ & 11 & 6 & 5 & 0 \\
\hline 3 & $\begin{array}{l}\text { S1 Non Ilmu } \\
\text { Perpustakaan }\end{array}$ & & & & \\
4 & $\begin{array}{l}\text { Semua Jurusan } \\
\text { Ilmu Komputer }\end{array}$ & 1 & 7 & 0 & $6^{*}$ \\
dan Jaringan & 1 & 1 & 0 & 0 \\
\hline 5 & $\begin{array}{l}\text { D3 Perpustakaan } \\
\text { SLTA }\end{array}$ & 3 & 23 & 0 \\
\hline & $\begin{array}{l}\text { SMA semua } \\
\text { jurusan }\end{array}$ & 7 & 7 & 0 & 1 \\
\hline Jumlah & 48 & 26 & 28 & 7 \\
\hline
\end{tabular}

*Tenaga yang berlebih adalah tenaga yang tidak memenuhi kualifikasi pendidikan yang sesuai dengan job description di masingmasing koordinator layanan.

Tabel di atas, menggambarkan tentang kondisi kebutuhan SDM perpustakaan yang ideal sesuai dengan kebutuhan layanan perpustakaan saat ini. Tenaga yang dibutuhkan adalah tenaga professional (pustakawan tingkat ahli/S1 Ilmu Perpustakaan), dan tenaga paraprofessional (Pustakawan tingkat trampil/D3 Perpustakaan).

Tenaga yang berlebih yang dimaksud adalah tenaga yang tidak memenuhi kualifikasi pendidikan yang sesuai dengan job description di masing-masing koordinator layanan. Untuk menjadikan tenaga berlebih sesuai dengan kebutuhan, diperlukan pendidikan dan pelatihan perpustakaan melalui kegiatan yang diselenggarakan oleh Perpustakaan Nasional Republik Indonesia.

Pemetaan ini sangat penting dilakukan karena berdasarkan hasil survey mutu layanan di atas, salah satu pemicu ketidakpuasan pemustaka disebabkan oleh ketidakmampuan staf dalam memberikan pelayanan. Ketidakmampuan ini disebabkan antara lain, kualifikasi pendidikan yang tidak sesuai, dan kurangnnya pemahaman terhadap tugas-tugas librarianship. 
d. Mekanisme Pemenuhan Kebutuhan SDM Perpustakaan Mekanisme pemenuhan kebutuhan SDM didasarkan pada perencanaan dan pengembangan SDM (kualitatif dan kuantitatif) yang searah dengan pengembangan perpustakaan. Kebutuhan SDM yang termaktub dalam babsebelumnya dapat dibuat sebuah perencanaan secara berkelanjutan dan direncanakan terpenuhi dalam lima tahun kedepan. Tabel 6-7 adalah sebuah contoh mekanisme untuk memenuhi kebutuhan SDM dari aspek kualitatif dan kuantitatif.

Tabel 6. Pengembangan SDM Pusat Perpustakaan berdasarkan Aspek Kuantitatif

\begin{tabular}{|c|c|c|c|c|c|c|c|c|c|}
\hline \multirow{3}{*}{ No. } & \multirow{3}{*}{$\begin{array}{c}\text { Jenis } \\
\text { kebutuhan }\end{array}$} & \multicolumn{4}{|c|}{$\begin{array}{c}\text { Rencana Pengembangan } \\
\text { Jumlah Tenaga Tahun } \\
\text { Ke- }\end{array}$} & \multirow{3}{*}{$\begin{array}{l}\text { Jml } \\
\text { Total }\end{array}$} & \multirow{3}{*}{$\begin{array}{l}\text { Meka- } \\
\text { nisme } \\
\text { Pemenu- } \\
\text { han }\end{array}$} & \multirow{2}{*}{\multicolumn{2}{|c|}{$\begin{array}{l}\text { Sumber } \\
\text { Biaya }\end{array}$}} \\
\hline & & \multirow{2}{*}{$\begin{array}{c}I \\
2016\end{array}$} & \multirow{2}{*}{$\begin{array}{c}\text { II } \\
2017\end{array}$} & \multirow{2}{*}{$\begin{array}{c}\text { III } \\
2018\end{array}$} & \multirow{2}{*}{$\begin{array}{c}\text { IV } \\
2019\end{array}$} & & & & \\
\hline & & & & & & & & PNBP & $\mathrm{RM}$ \\
\hline I & $\begin{array}{l}\text { Tenaga } \\
\text { Pustakawan } \\
\text { Tingkat Ahli }\end{array}$ & & & & & & & & \\
\hline 1 & $\begin{array}{l}\text { S1 Ilmu } \\
\text { Perpustakaan }\end{array}$ & 2 & 2 & 1 & 0 & 5 & Kontrak & $\sqrt{ }$ & - \\
\hline \multirow[t]{2}{*}{ II } & $\begin{array}{l}\text { Tenaga } \\
\text { Pustakawan } \\
\text { Tingkat } \\
\text { trampil }\end{array}$ & & & & & & & & \\
\hline & $\begin{array}{l}\text { D3 Ilmu } \\
\text { Perpustakaan }\end{array}$ & 5 & 5 & 6 & 7 & 23 & Kontrak & $\sqrt{ }$ & - \\
\hline \multirow[t]{2}{*}{ III } & Tenaga TI & & & & & & & & \\
\hline & $\begin{array}{l}\text { S1 Ilmu } \\
\text { Komputer } \\
\text { dan Jaringan } \\
\end{array}$ & 0 & 0 & 0 & 0 & 0 & Kontrak & $\sqrt{ }$ & - \\
\hline IV & $\begin{array}{l}\text { Tenaga } \\
\text { Asisten } \\
\text { Pustakawan } \\
\end{array}$ & & & & & & & & \\
\hline \multirow[t]{2}{*}{1} & $\begin{array}{l}\text { SMA Semua } \\
\text { Jurusan }\end{array}$ & 0 & 0 & 0 & 0 & 0 & $\begin{array}{l}\text { Pramu- } \\
\text { bakti }\end{array}$ & $\sqrt{ }$ & - \\
\hline & Jumlah total & 7 & 7 & 7 & 7 & 28 & & & \\
\hline
\end{tabular}


Tabel 7. Pengembangan SDM Pusat Perpustakaan berdasarkan Aspek Kualitatif

\begin{tabular}{|c|c|c|c|c|c|c|c|}
\hline \multirow[t]{2}{*}{ No. } & \multirow[t]{2}{*}{ Jenis Pengembangan } & \multicolumn{5}{|c|}{$\begin{array}{c}\text { Rencana Pengembangan Tahun } \\
\text { Ke- }\end{array}$} & \multirow{2}{*}{$\begin{array}{c}\text { Target } \\
\text { Pencapaian }\end{array}$} \\
\hline & & $\mathrm{I}$ & II & III & IV & $\mathrm{V}$ & \\
\hline & & 2015 & 2016 & 2017 & 2018 & 2019 & \\
\hline 1 & $\begin{array}{c}\text { Meningkatkan } \\
\text { kemampuan bahasa } \\
\text { arab dan inggris } \\
\text { pustakawan }\end{array}$ & $\sqrt{ }$ & $\sqrt{ }$ & $\sqrt{ }$ & $\sqrt{ }$ & $\sqrt{ }$ & $70 \%$ \\
\hline 2 & $\begin{array}{c}\text { Meningkatkan } \\
\text { kemampuan spiritual } \\
\text { pustakawan }\end{array}$ & $\sqrt{ }$ & $\sqrt{ }$ & $\sqrt{ }$ & $\sqrt{ }$ & $\sqrt{ }$ & $100 \%$ \\
\hline 3 & $\begin{array}{l}\text { Mengikutsertakan } \\
\text { pustakawan dalam } \\
\text { pelatihan-pelatihan } \\
\text { yang menunjang } \\
\text { peningkatan } \\
\text { kompetensi } \\
\text { pustakawan }\end{array}$ & $\sqrt{ }$ & $\sqrt{ }$ & $\sqrt{ }$ & $\sqrt{ }$ & $\sqrt{ }$ & $70 \%$ \\
\hline 4 & $\begin{array}{c}\text { Mengikutsertakan } \\
\text { DIKLAT CPTAdan } \\
\text { TEKNIS bagi staf } \\
\text { perpustakaan yang } \\
\text { berlatarbelakang non } \\
\text { perpustakaan }\end{array}$ & $\sqrt{ }$ & $\sqrt{ }$ & $\sqrt{ }$ & $\sqrt{ }$ & $\sqrt{ }$ & $100 \%$ \\
\hline 5 & $\begin{array}{c}\text { Meningkatkan } \\
\text { kinerja dan } \\
\text { pelayanan } \\
\text { pustakawan }\end{array}$ & $\sqrt{ }$ & $\sqrt{ }$ & $\sqrt{ }$ & $\sqrt{ }$ & $\sqrt{ }$ & $100 \%$ \\
\hline
\end{tabular}

\section{Simpulan}

SDM Pusat Perpustakaan UIN Malang, baik secara kualitas maupun kuantitas, masih kurang memadai. Secara kuantitas, SDM perpustakaan masih kurang 22 pegawai. Dan secara kualitas, kompetensi SDM perpustakaan masih sedikit yang berlatar belakang pendidikan ilmu perpustakaan.

Persentase dan skor kepuasan pemustaka berdasarkan mutu layanan perpustakaan secara keseluruhan pada lima aspek 
yang dikaji yaitu reliability (74\% / 3.7), responsiveness $(75 \%$ / 3.8), assurance (71\% / 3.5), emphaty (66\% / 3.3), dan tangible (69\% / 3.5), maka aspek empati staf perpustakaan yang paling rendah. Dari persentase dan skor tersebut Pusat Perpustakaan UIN Maulana Malik Ibrahim Malang secara keseluruhan mampu memberikan pelayanan cukup memuaskan. Namun demikian masih terdapat jawaban sebagian kecil responden yang menilai pelayanan perpustakaan tidak memuaskan. Khususnya pada aspek empati staf terhadap pemustaka yang paling besar.

Beban kerja staf dan tingkat kompetensi dalam menjalankan tugas-tugas perpustakaan memiliki hubungan kuat dengan mutu layanan perpustakaan. Beban kerja staf yang berlebih berdampak pada mutu pelayanan yang diberikan. Karena berdasarkan hasil survey mutu layanan, salah satu pemicu ketidakpuasan adalah ketidakmampuan staf dalam memberikan pelayanan kepada pemustaka.

Demikian hasil penelitian ini, semoga dapat menjadi bahan informasi bagi perencanaan pengembangan SDM Pusat Perpustakaan UIN Maulana Malik Ibrahim Malang ke depan dalam rangka menuju universitas kelas dunia (toward world class University). 


\section{DAFTAR PUSTAKA}

Awan, Muhammad Usman, S Azam, and Muhammad Asif. "Library Service Quality Assessment." Journal of Quality and Technology Management 4, no. 1, 2008.

Hariyono, W, D Suryani, and Y Wulandari. "Hubungan Antara Beban Kerja, Stres Kerja Dan Tingkat Konflik Dengan Kelelahan Kerja Perawat Di Rumah Sakit Islam Yogyakarta Pdhi Kota Yogyakarta." Kesmas 3, no. 3, 1978.

_-_. "Hubungan Antara Beban Kerja, Stres Kerja Dan Tingkat Konflik Dengan Kelelahan Kerja Perawat Di Rumah Sakit Islam Yogyakarta PDHI Kota Yogyakarta." Kesmas 3, no. 3, 2009, http://jogjapress.com/index.php/KesMas/article/ view/546.

Kemenpan-RB RI. Peraturan Menteri Pendayagunaan Aparatur Negara Nomor Dan Reformasi Birokrasi Republik Indonesia Nomor 9 Tahun 2014 Tentang Jabatan Fungsional Pustakawan Dan Angka Kreditnya. Indonesia, 2014.

Kementerian Agama RI. Keputusan Menteri Agama Republik Indonesia Nomor 164 Tahun 2010 Pedoman Pelaksanaan Analisis Beban Kerja (Workload Analysis) Di Lingkungan Kementerian Agama. Jakarta: Kementerian Agama RI, 2010.

Kementerian Sekretaris Negara RI. "Peraturan Pemerintah Republik Indonesia Nomor 24 Tahun 2014 Tentang Pelaksanaan Undang-Undang Nomor 43 Tahun 2007 Tentang Perpustakaan." Jakarta, 2014.

Mufid. "Pengaruh Mutu Layanan Terhadap Kepuasan Pemustaka: Studi Kasus Di Perpustakaan Pusat UIN Maulana Malik Ibrahim Malang." Universitas Indonesia, 2011. http:// repository.uin-malang.ac.id/693/.

Parasuraman, A, Valarie A Zeithaml, and Leonard L Berry. "Servqual: Multiple Item Scale for Measuring Consumer Perseption of Service Quality." Journal of Retailing 64, no. 1 (1988): 12-40. 
Samosir, Zurni Zahara, and Iin Syahfitri. "Faktor Penyebab Stres Kerja Pustakawan Pada Perpustakaan Universitas Sumatera Utara." Pustaha 4, no. 2 (2008): 60-69. http://ced.petra. ac.id/index.php/pus/article/download/17236/17191.

Sureshchandar, G S, C Rajendran, and R N Anantharaman. "The Relationship between Service Quality and Customer Satisfaction - Afactor-Specific Approach." Journal of Service Marketing 16, no. 4 (2002): 363-79.

The Special Libraries Association. "Competencies for Information Professionals of the 21st Century." The Special Libraries Association, 2003. http://sla.org/wp-content/ uploads/2013/01/0\{_\}LRNCompetencies $2003\left\{\_\right\}$ revised. pdf.

UIN Malang. Implementasi Sistem Manajemen Mutu ISO 9001:2000 Di Universitas Islam Negeri (UIN) Malang. Malang: UIN Malang, 2008.

-_- Rencana Strategis UIN Malang 2005-2030. Malang: UIN Malang, 2005.

Werner, Jon M, and Randy L DeSimone. Human Resource Development. South-Western Cengage Learning, 2011. 
Halaman ini bukan sengaja untuk dikosongkan 